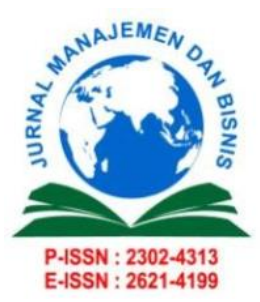

\title{
Jurnal Manajemen dan Bisnis
}

Vol. 9, No. 2, December 2020, pp. 61-72

\section{Sekolah Tinggi Ilmu Ekonomi Indragiri (STIE-I) Rengat}

https://journal.stieindragiri.ac.id/index.php/jmbi/issue/view/15

\section{THE ROLE OF SOCIAL MEDIA IN INCREASING MARKET SHARE OF MSME PRODUCTS IN PEMATANGSIANTAR CITY}

\author{
Sherly'), Fitria Halim ${ }^{2)}$, Acai Sudirman ${ }^{3)}$ \\ 1) 2) 3) Management Study Program, Sekolah Tinggi Ilmu Ekonomi Sultan Agung \\ ${ }^{1)}$ sherly@ stiesultanagung.ac.id ${ }^{2}$ fitriahalim2839@ stiesultanagung.ac.id ${ }^{3)}$ acaivenly@ stiesultanagung.ac.id \\ Submited: 2020.11.04 Reviewed: 2020.12.07 Accepted: 2020.12.27 \\ https://doi.org/10.34006/jmbi.v9i2.206
}

\begin{abstract}
Abstrak
Meningkatnya market share produk tidak terlepas dari keterhubungan sistem dan media pemasaran yang digunakan. Saluran pemasaran berperan penting dalam meningkatkan penjualan dalam jangka pendek maupun jangka panjang. Penelitian ini memiliki tujuan untuk mengetahui peran media sosial dalam meningkatkan market share produk UMKM di Kota Pematangsiantar. Desain dalam penelitian ini menggunakan model studi kepustakaan dan studi lapangan dengan pendekatan kualitatif dengan one shot model. Lokasi penelitian dilakukan pada 8 kecamatan yang ada di Kota Pematangsiantar. Populasi dalam penelitian ini adalah pelaku UMKM yang tersebar di 8 kecamatan yang ada di Kota Pematangsiantar dengan pengambilan sampel menggunakan teknik nonprobability sampling dengan teknik purposive sampling, sehingga diperoleh jumlah sampel sebesar 240 responden. Selanjutnya teknik analisis data yang dipergunakan dalam penelitian ini adalah analisis data dengan model reduksi data yang berasal dari pengumpulan data dan display data. Hasil penelitian ini menyimpulkan bahwa penggunaan media sosial sangat dominan dilakukan oleh pelaku UMKM pada sektor mikro dan instagram merupakan salah satu jenis media sosial yang sering digunakan. Lebih lanjut hasil penelitian juga menyimpulkan bahwa faktor waktu merupakan hal yang mendasari pelaku UMKM menggunakan media sosial sebagai media promosi produknya.
\end{abstract}

Kata kunci: Media Sosial, Market Share, UMKM

\begin{abstract}
The increase in product market share cannot be separated from the connectivity of the marketing system and media used. Marketing channels play an important role in increasing sales both in the short and long term. This study aimed to determine the role of social media in increasing the market share of MSME products in Pematangsiantar City. The research design used a literature study and field study models using a qualitative approach with a one-shot model. The research location was in 8 districts in Pematangsiantar City. The population in this study were MSME players scattered in 8 districts in Pematangsiantar City. The samples were collected using a non-probability sampling technique with purposive sampling technique, so that a total sample size of 240 respondents were obtained. Moreover, the data analysis technique used in this study was data analysis with a data reduction model that was obtained from data collection and data display. The results of this study concluded that the use of social media was very dominant in MSME players in the micro sector and Instagram was one type of social media that was often used. Furthermore, the results of the study also suggested that the time factor was the basis for MSME players using social media as a medium for promoting their products.
\end{abstract}

Keywords: Social Media, Market Share, MSME

Vol. 9, No. 2, December 2020, pp. 61-72 


\section{INTRODUCTION}

The development of micro, small and medium enterprises has given a positive impact on national employment (Maya, 2016). Micro, small and medium enterprises are productive economic categories that are owned by individuals or business entities in accordance with the criteria stipulated in Law Number 20 of 2008. One of the factors that stimulate the growth in the number of MSME players was marked by the development of online promotional media (Setiawan et al., 2018). Based on data from the Indonesian Ministry of Cooperatives and SMEs, it is known that the total market share of MSMEs in 2017 was approximately $99.99 \%$ (62.9 million units) of the total existing market share and the employment was 116.63 million $(97.05 \%)$, while that of large-scale businesses was only about $0.01 \%$ (5400 units) and the employment was $2.95 \%$ or 3.58 million (Haryanti \& Isniati, 2018). The development of the national MSME market share is inseparable from the role of speed of access via the internet using social media platforms. In line with the dynamics of changes in innovation in entrepreneurship, every UMKM business player is faced with quite tough challenges in accordance with the existence and development of their business (Akmad, 2015). Electronic marketing or internet marketing is now no longer unfamiliar to the world of business and industry, as the establishment of the digital world increasingly facilitates consumers and business players to develop market shares to increase company effectiveness and efficiency. The use of social media by every business player does not only develop in terms of communication skills, but can also adopt more modern technological innovations (Papa et al., 2018). More specifically, every enterprise or business player can increase their business innovation by consolidating competitors, knowledge, and experience with a database of social media usage (Jones et al., 2015).

The manifestation of the social media reputation has created a new mindset for the community, especially those who use e-commerce (Purwantini \& Anisa, 2018). The process of transferring communication from the community or individual development is a reflection of communication patterns on social media which are then transferred to the virtual world or the communication is carried out virtually. Social commerce is formed because of the increasing human interaction with smartphones or other gadgets in online shopping (Purwantini \& Anisa, 2018). The community who act as followers can adopt digital marketing using social media with the expectation of reaching various lines of community. The urgency of the use of social media by MSME players is as an effective communication medium in helping to make business decisions (Priambada, 2015). Social media platforms are increasingly being adopted by enterprise or business players as the newest marketing instrument. Social media presence acts as an additional tool for connecting them with their customers and is used effectively to attract new customers and engage existing customers (Verma \& Shaiba, 2019). The role of social media is expected to encourage the interest of business players to carry out business activities optimally.

For business players who establish an internet-based marketing model, the opportunity to develop their business is very high if it is supported by the knowledge of internet use holistically (Kader et al., 2018). Meanwhile, social media has influenced widespread evolution in information structures and accessibility with an extraordinary role in the diversity of market investments (Bulearca \& Bulearca, 2010). The decision of SMEs to use social media as an approach to implement entrepreneurship is a strategic decision. It can be considered as a defensive reaction to environmental changes that mediate the resources and activities of the company with the aim of maintaining performance at a high level (Dutot \& 
Bergeron, 2016). The government is currently committed and makes efforts to accelerate access and technology transfer as a stimulus to encourage innovative SME players to compete with foreign SME players (Slamet et al., 2016). Based on the results of a survey conducted by APJII (2018), for the total population of Indonesia of 264.16 million people, more than 171.17 million Indonesians were connected to the internet, most of whom were in Java Island, with a total of 143.26 million people. This condition illustrates that the use of the internet has a fairly high business opportunity.

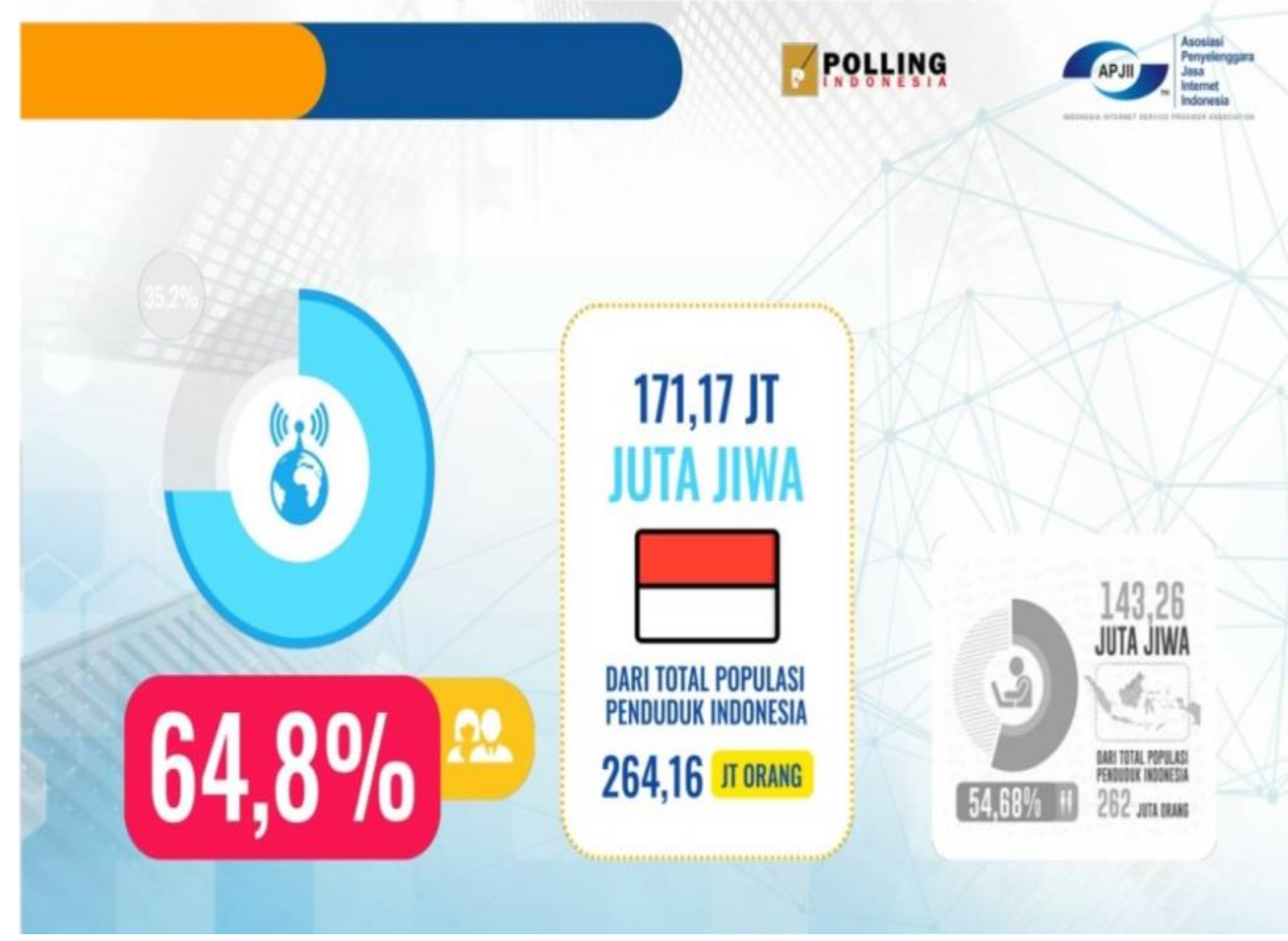

Figure 1. Internet Users in Indonesia in 2018

Source: (APJII, 2018)

Social media is an online media which is used as a means of online social interaction on the internet. On social media, users can communicate, interact, share, build a network, and carry out various other activities with each other. According to Kotler \& Keller (2016), social media is part of the facility for consumers to share information of the forms of text, image, video, and audio with each other and with companies and vice versa. The rapid development of internet technology is marked by the delivery of communication that is quickly received by a person without any limitation of place and time (Kader et al., 2018). Social media applications have a relatively popular platform through live videos and stories. This is used as an approach to the audience with the concept of offered direct interaction. The role of social media in spreading product information can increase a wider market share compared to other print or electronic media. Through technological transformation, it is expected that it can improve the business model which is oriented towards the acceleration of a high amount of information exchange (Irianto, 2015). The urgency of marketing mix orientation, such as promotion, is one of the steps taken by business players in increasing the market share of their products (Apriansyah, 2018). The orientation of economic development in Pematangsiantar City is directed at aspects that can increase economic growth at the moment, 
one of which is modernization and economic growth by considering the aspects of the equal income distribution, employment opportunities, population growth rates, and changes in the regional economic structure. The economic growth of Pematangsiantar City, which is increasingly better, must certainly be supported by an increase in the market share of MSME products so that the income earned by MSME players can improve the economy of Pematangsiantar City. The high growth of the national MSME market share was not followed by the growth in the number of MSMEs in each city, especially Pematangsiantar City. This condition occurs due to the lack of information provided by MSME actors to consumers in marketing their products through social media and the insufficient understanding of MSME players in choosing types of social media that support their marketing system. The urgency of this study is to determine the activities of using social media by MSME actors and the impact of social media on the market share of MSME products in Pematangsiantar City.

\section{RESEARCH METHODS}

This study was conducted using a qualitative approach with a one-shot model. The research design used a field study and literature study. The selection of the locations was adjusted to the number of MSMEs in each sub-district in the East Siantar, West Siantar, North Siantar, South Siantar, Siantar Marihat, Siantar Martoba, Siantar Sitalasari, Siantar Marimbum Districts. The population in this study was from primary and secondary data, including the total number of MSMEs in Pematangsiantar City obtained through observations and documentations of the Statistics Indonesia of Pematangsiantar City. Based on data from the Statistics Indonesia of Pematangsiantar City in 2015, it is known that the number of small industrial enterprises was in the range of 537 business units. The sampling was carried out proportionally using a proportional sampling technique (Arikunto, 2016). Thus, the number of samples for each district in this study was 30 enterprise or business players that were categorized as MSMEs with a total of 240 samples. The data collection process used the methods of observation, documentation and structured interviews using a questionnaire. Next, the data analysis process was carried out by reducing the data from data collection and data display, then the data were verified to obtain conclusions (Sugiyono, 2017). Interpretation of data processing using the reduction method can be carried out by grouping the collected data with standardization based on the problem category in the study.

\section{RESULTS AND DISCUSSION}

\section{Overview of Respondents}

The sampling was carried out proportionally using a proportional sampling technique. Thus, the number of samples for each district in this study which was spread in 8 districts, including East Siantar, West Siantar, North Siantar, South Siantar, Siantar Marihat, Siantar Martoba, Siantar Sitalasari, and Siantar Marimbun Districts was 30 enterprise or business players that were categorized as MSMEs with a total of 240 samples. Based on the results of the study that has been carried out in the field, it obtained the number of MSME players in Pematangsiantar City as follows: 


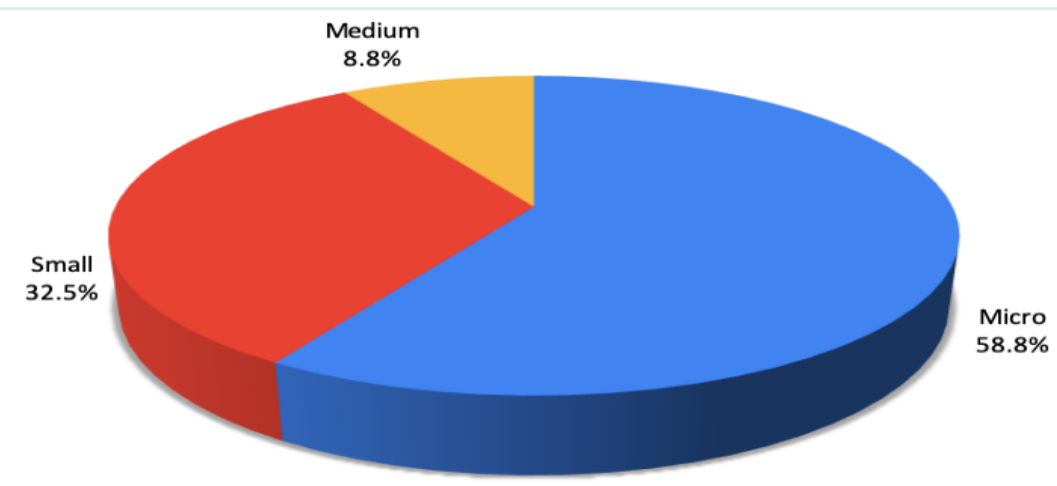

Figure 2. MSME Categories

Source: Processed Data (2020)

Based on Figure 2 above, it showed that the distribution of the characteristics of the research sample consisted of 141 micro enterprises, 78 small businesses, and 21 medium enterprises. This shows that the category of micro businesses spread over 8 districts was more dominant in number. The improving economic growth of Pematangsiantar City was in line with the improvement in the regional and national economy which had provided a significant impact on locally-generated revenue and was supported by the increasing growth of MSMEs. The majority of business players developing in Pematangsiantar City were micro and smallscale enterprises. Therefore, there needs to be special attention from local governments in developing the micro and small sectors in the future.

\section{Results of the Study}

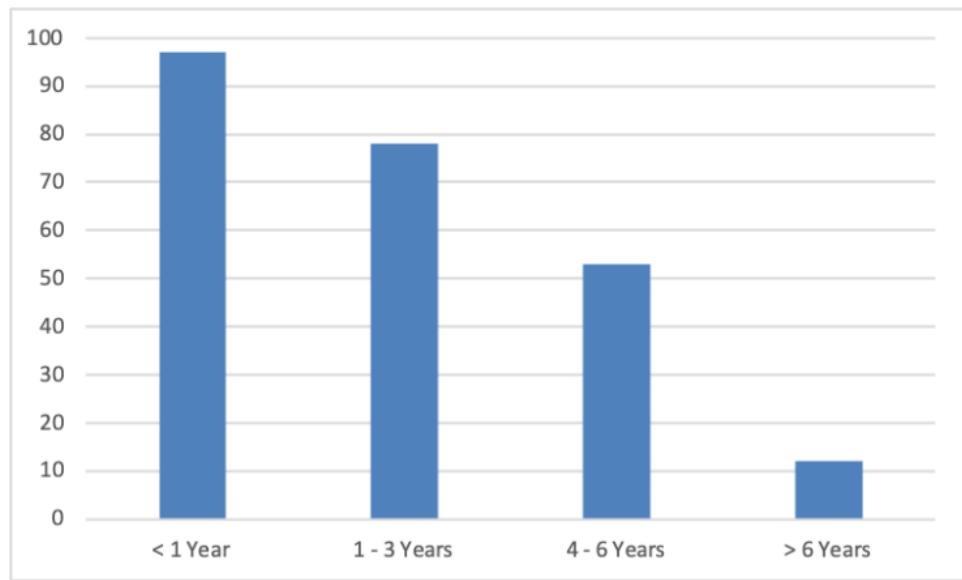

Figure 3. Length of Business Operation Source: Processed Data (2020)

Based on Figure 6 above, it showed that 97 business players had a length of business operation of less than 1 year, 78 business players had a length of business operation of 1 to 3 years, then 53 business players had a length of business operation of 4 to 6 years, while 12 business players had a length of business operation of more than 6 years. 


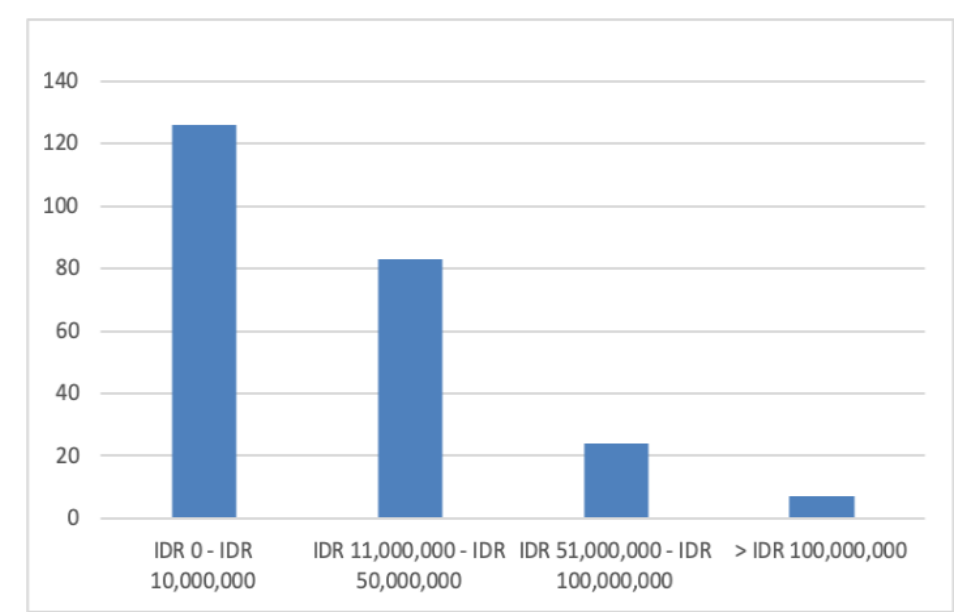

Figure 4. Total Initial Capital

Source: Processed Data (2020)

Based on Figure 4 above, it showed that 126 business players required initial capital to run the business ranging from 0 to 10 million, then 83 business players required initial capital to run the business ranging from 11 to 50 million, then 24 business players required initial capital to run the business ranging from 51 to 100 million, and the last, 7 business players required initial capital to run the business of more than 100 million. Furthermore, it showed that the average amount of capital required to start a business was in the range of IDR 0 to IDR 10,000,000. This condition showed that the micro sector had a higher involvement in economic turnover in Pematangsiantar City.

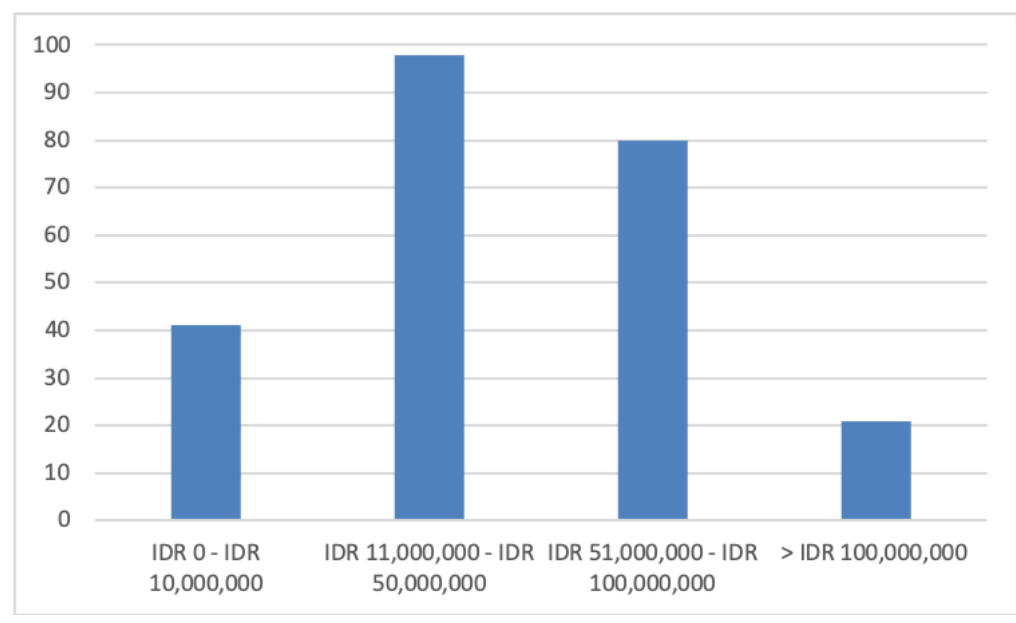

Figure 5. Business Capital Value

Source: Processed Data (2020)

Based on Figure 5 above, it showed that 41 business players had a current capital value ranging from 0 to 10 million, then 98 business players had a current capital value ranging from 11 to 50 million, while 80 business players had a current capital value ranging from 51 to 100 million, and the last, 21 business players had a current capital value of more than 100 million. 


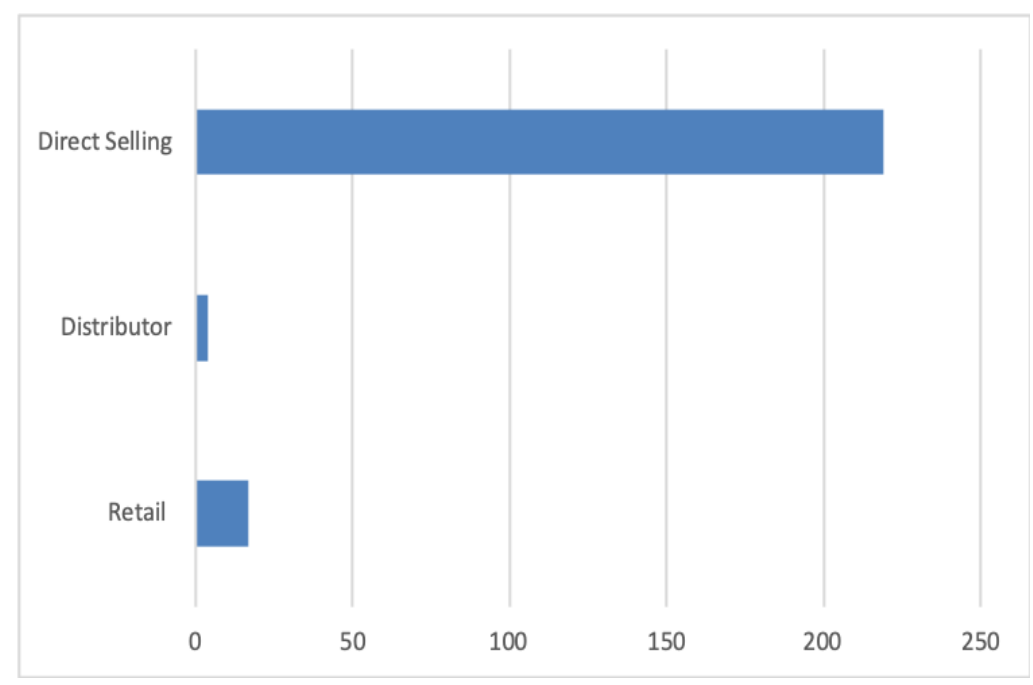

Figure 6. Product Selling System

Source: Processed Data (2020)

Based on Figure 6 above, it showed that 219 business players used the direct selling system, 4 business players used the distributor selling system, and 17 business players used the retail selling system.

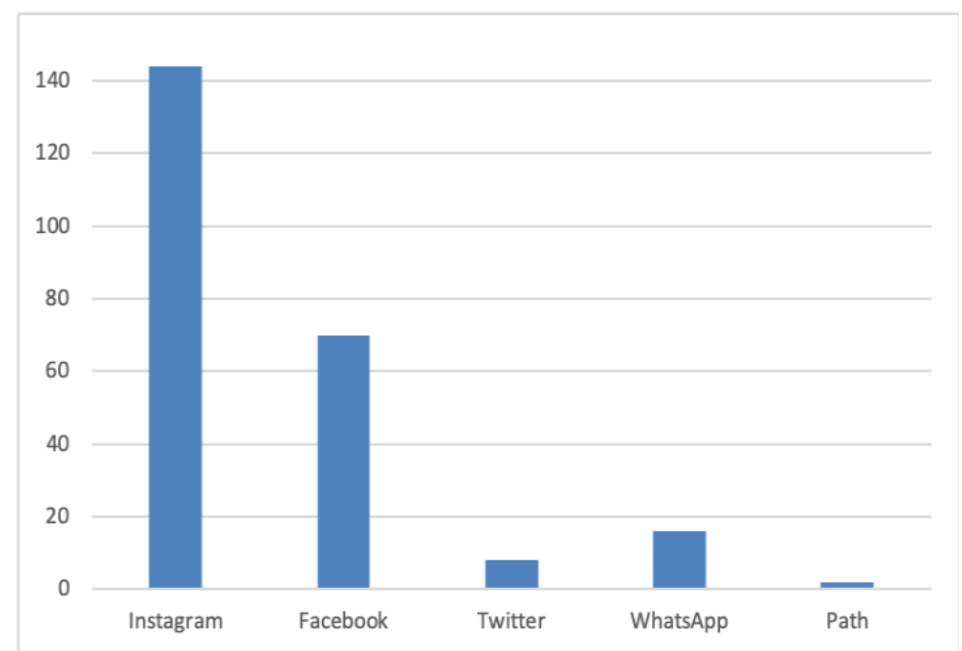

Figure 7. Frequently Used Social Media

Source: Processed Data (2020)

Based on Figure 7 above, it showed that 144 business players used social media of Instagram as a marketing medium in promoting their products. Then, 70 business players used social media of Facebook as a marketing medium in promoting their products. Furthermore, 8 business players used social media of Twitter as a marketing medium in promoting their products. Besides, 16 players used social media of WhatsApp as a marketing medium in promoting their products, and 2 business players used social media of Paths as a marketing medium in promoting their products. 


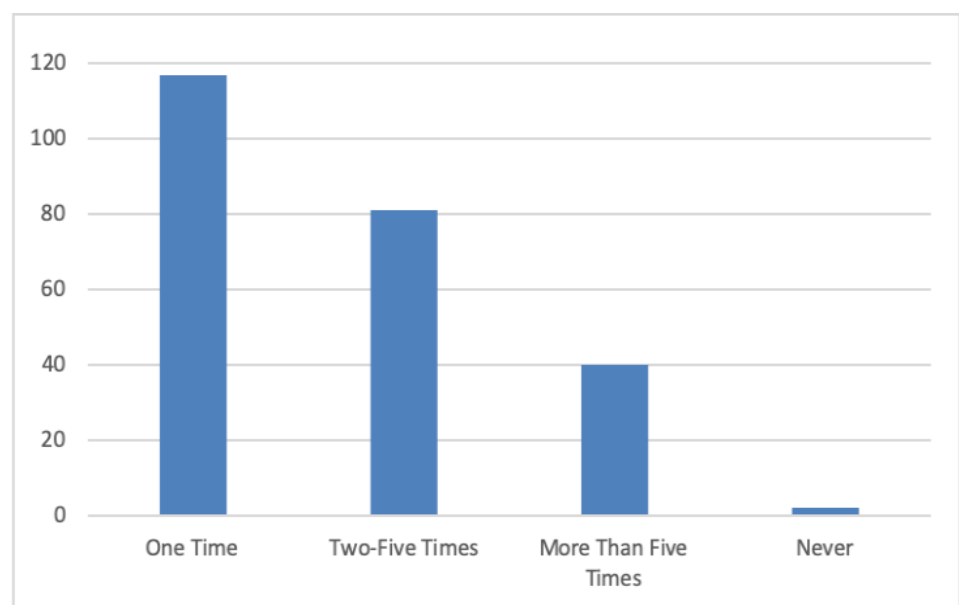

Figure 8. The intensity of Using Social Media Source: Processed Data (2020)

Based on Figure 8 above, it showed that 117 business players used social media with a frequency of use of 1 time a day. Then, 81 players used social media with a frequency of use of 2 to 5 times a day. Furthermore, 40 players used social media with a frequency of use of more than 5 times a day, and 2 business players never used social media at all.

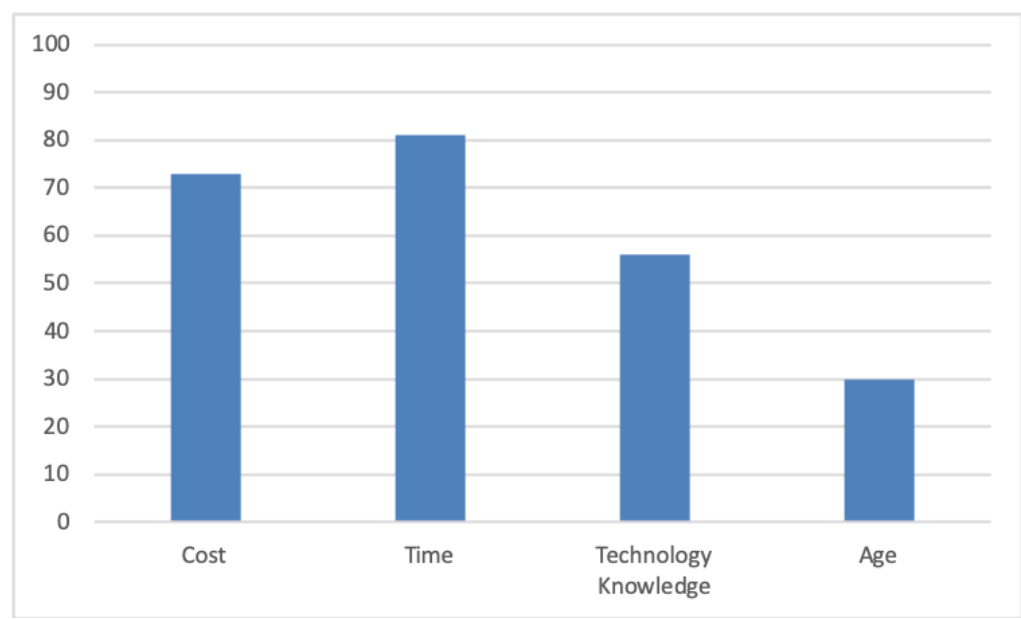

Figure 9. Factors that Accelerate Social Media Use Source: Processed Data (2020)

Based on Figure 9 above, it showed that 73 business players stated that the reason for using the media in promoting their products was due to the cost factor. Furthermore, 81 business players stated that the reason for using the media in promoting their products was due to the time factor. Then, 56 business players stated that the reason for using the media in promoting their products was due to the technological knowledge factor, and 30 business players stated that the reason for using the media in promoting their products was due to the age. 


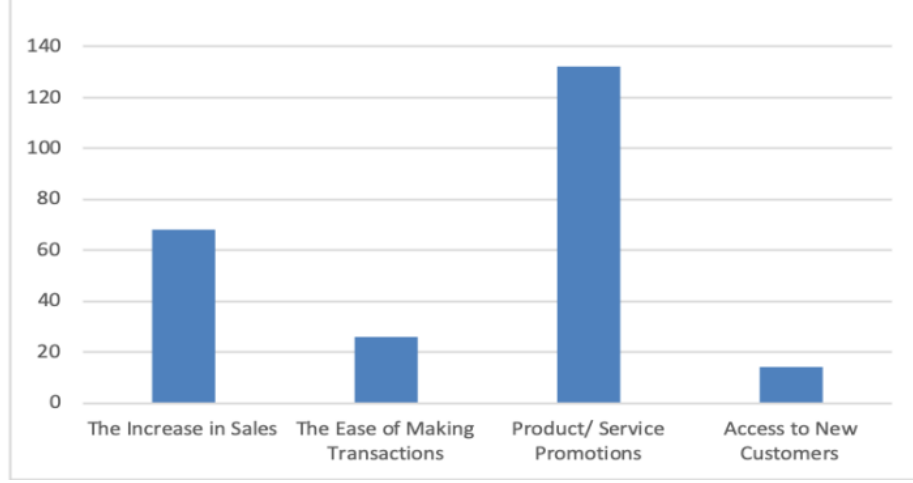

Figure 10. Benefits of Using Social Media

Source: Processed Data (2020)

Based on Figure 10 above, it showed that 68 business players stated that the convenience obtained by using social media was the increase in sales. Then, 26 business players stated that the convenience obtained by using social media was the ease of making transactions. Furthermore, 132 business players stated that the convenience obtained by using social media was the effectiveness of carrying out product promotions. Besides, 14 business players stated that the convenience obtained by using social media was access to new customers.

\section{Discussion}

Today's communication and marketing collaborations with social media aim to promote the effective and timely exchange of information throughout the business supply chain (Cao et al., 2018). The existence of market orientation is inseparable from the role of market access in bridging sellers and buyers. This condition illustrates that market access in contemporary marketing is crucial to be considered and developed. The increase in the market share of MSME products needs to be oriented towards broad market access with the expectation of having a high and measurable market share. Information disclosure to find out which products will be provided in the target market is important for potential buyers to obtain sustainable information about these products (Siregar et al., 2020). Research Yasa et al., (2020), also conveyed the same results as this study with the finding that the higher the promotion strategy using social media, the higher the business performance of SMEs. Promotional activities using social media can increase sales turnover, market share and business profits (Zhang \& Ahmed, 2018). Results of studies conducted (Kaplan \& Haenlein, 2010), proving that business development is inseparable from the involvement of the use of social media which has the implication of increasing high efficiency than using traditional marketing communications.

Based on the observations made, micro, small and medium enterprises (MSMEs) in Pematangsiantar still had limited market access where the majority of products produced were still offered in the local market. To overcome this, MSME entrepreneurs can expand their market access by carrying out online marketing, such as via market place websites. In its implementation, MSME entrepreneurs must be able to select the right online marketing channel to reach optimal results (Chikandiwa et al., 2013). For example, for MSME entrepreneurs who produce perishable products, such as food, suitable marketing channels such as Grabfood, Gofood, Jaket, etc. can be used to assist them in reaching further local markets. This had indeed been implemented or had been used by some food and beverage 
culinary businesses in Pematangsiantar. However, in its application, it was still less than optimal where there were still some MSME entrepreneurs who were not updated with the product types and product prices offered, so that the consumers become less satisfied when ordering via the application (Omotosho, 2020). Meanwhile, for MSME entrepreneurs who produce or sell durable products, such as ulos, spare parts, etc., they can take advantage of the existing e-commerce (such as Lazada, Bukalapak, and Tokopedia) to help entrepreneurs reach a wider market.

Promotion and product image were activities carried out by MSMEs in Pematangsiantar City to try to introduce products to be known by the wider community. Some of the problems faced by MSMEs in Pematangsiantar City were related to promotion and product image, which was the lack of product introduction carried out by MSMEs, in this case including promotion through local product exhibitions in collaboration with the Office of Cooperatives, SME, and Trades, still lacking in utilizing and managing promotions and product image via digital marketing media (for example social media), and not maximally promoting by word of mouth marketing. Ahmad et al., (2019) studies, suggests that the decision to adopt technology using social media is believed to be able to increase the company's competitiveness and market share. Although using social media makes it easier for entrepreneurs to introduce their products, it cannot be denied that there are risks if their use is without rules, because social media is a communication tool that is on an information technology (IT) platform that has the potential to experience the risk of information leakage (Demek et al., 2018). Social media emphasizes the importance of a digital business strategy which basically changes the way entrepreneurs communicate, collaborate, consume, and create (Garcia-Morales et al., 2017).

The combination of goods and services created by the company and then offered to market orientation is an alternative to support this promotion (Herlambang, 2014). The marketing mix used in the promotion process using social media should consist of a brand, good packaging, service, assurance, quality, and characteristics. Orare \& Nkrina, (2019) studies, recommends that MSMEs using marketing channels with online stores need to do more in terms of creating awareness about the benefits of online shopping to consumers. The solution to encounter this problem is that MSME players should be provided with assistance or have willing to learn from experiences shared by many local and national entrepreneurs and learn from many books, social networks, or through continuous training seminars and skill-oriented in terms of promotion and product image. Besides, business players are also strongly suggested to join a business community that can bring together MSME players with many other entrepreneurial practitioners with an expectation of exchanging creative ideas in using social media as a medium for promoting their products.

\section{CONCLUSION}

To increase the capacity and opportunities for product innovation, it can be carried out by utilizing technology-based marketing channels and there should be training and mentoring activities for MSME players regarding the effectiveness of using social media. This aims to encourage MSME players to make use of digital marketing by using social media in promoting their products to compete in market share. The use of social media as a promotional media is expected to optimally increase the market share of MSME products. In addition, to expand market access, it is recommended that MSME entrepreneurs be able to carry out online marketing, such as Grabfood, Gofood, Jaket, etc. for food product categories, and e-commerce, such as Lazada, Bukalapak, Tokopedia, etc. for durable product categories. 


\section{ACKNOWLEDGEMENT}

On this occasion, the writing team would like to thank DRPM for the funding budget provided to the National Competitive Research for Beginner Lecturer Research Scheme for the year 2020. The author team also wishes to express their deepest gratitude to all parties involved in the research completion process and writing of the article, to the Regional Development and Planning Agency (BAPPEDA) of Pematangsiantar City which has provided a research permit, the entire academic community of the Sultan Agung Economic Academy and to the team of editors and reviewers of the management and business journal managed by the Indragiri Rengat Economic Academy that always provide constructive input to refine this article.

\section{REFERENCES}

Ahmad, S. Z., Abu Bakar, A. R., \& Ahmad, N. (2019). Social media adoption and its impact on firm performance: the case of the UAE. International Journal of Entrepreneurial Behaviour and Research, 25(1), 84-111. https://doi.org/10.1108/IJEBR-08-2017-0299

Akmad, K. A. (2015). Pemanfaatan Media Sosial Bagi Pengembangan Pemasaran UMKM (Studi Deskriptif Kualitatif Pada Distro di Kota Pematangsiantar). Duta.Com, 9(1), 4353.

APJII. (2018). Hasil Survei Penetrasi dan Perilaku Pengguna Internet Indonesia 2018. https://www.apjii.or.id/content/read/39/410/Hasil-Survei-Penetrasi-dan-PerilakuPengguna-Internet-Indonesia-2018

Apriansyah, R. (2018). Pengaruh Kualitas Pelayanan Dan Promosi Terhadap Volume Penjualan Pada PT. Prioritas Rengat. Jurnal Manajemen Dan Bisnis, 7(2), 37-45. https://doi.org/10.34006/jmbi.v7i2.48

Arikunto, S. (2016). Prosedur Penelitian: Suatu Pendekatan P (Edisi 16). PT Rineka Cipta.

Bulearca, M., \& Bulearca, S. (2010). Twitter: a Viable Marketing Tool for SMEs? Global Business \& Management Research: An International Journal, 2(4), 296-309. http://ezlibproxy.unisa.edu.au/login?url=http://search.ebscohost.com/login.aspx?direct=t rue $\& \mathrm{db}=\mathrm{bth} \& \mathrm{AN}=57622388 \&$ site $=$ ehost-live

Cao, Y., Ajjan, H., Hong, P., \& Le, T. (2018). Using Social Media For Competitive Business Outcomes: An Empirical Study Of Companies In China. Journal of Advances in Management Research, 15(2), 211-235. https://doi.org/10.1108/JAMR-05-2017-0060

Chikandiwa, S. T., Contogiannis, E., \& Jembere, E. (2013). The Adoption Of Social Media Marketing In South African Banks. European Business Review, 25(4), 365-381. https://doi.org/10.1108/EBR-02-2013-0013

Demek, K. C., Raschke, R. L., Janvrin, D. J., \& Dilla, W. N. (2018). Do organizations use a formalized risk management process to address social media risk? International Journal of Accounting Information Systems, 28(December 2017), 31-44. https://doi.org/10.1016/j.accinf.2017.12.004

Dutot, V., \& Bergeron, F. (2016). From Strategic Orientation To Social Media Orientation: Improving Smes' Performance On Social Medi. Journal of Small Business and Enterprise Development, 23(4), 1165-1190. https://doi.org/https://doi.org/10.1108/JSBED-11-2015-0160

Garcia-Morales, V. J., Martín-Rojas, R., \& Lardón-López, M. E. (2017). Influence Of Social Media Technologies On Organizational Performance Through Knowledge And Innovation. Baltic Journal of Management, 13(3), 345-367. https://doi.org/10.1108/BJM-04-2017-0123 
Haryanti, D. M., \& Isniati, H. (2018). Potret UMKM Indonesia: Si Kecil Yang Berperan Besar. https://www.ukmindonesia.id/baca-artikel/62

Irianto, A. B. P. (2015). Pemanfaatan Social Media Untuk Meningkatkan Market Share UKM. Teknomatika, 8(1), 1-12.

Jones, N., Borgman, R., \& Ulusoy, E. (2015). Impact of Social Media on Small Businesses. Journal of Small Business and Enterprise Development, 22(4).

Kader, M. A., Mulyatini, N., \& Setianingsih, W. (2018). Model Pemasaran Digital Marketing FB_Ads dan Email Marketing Dalam Meningkatkan Volume Penjualan. Jurnal Ilmu Manajemen, 5(2), 299-305.

Kaplan, A. M., \& Haenlein, M. (2010). Users of the World, Unite! The Challenges and Opportunities of Social Media. Business Horizons, 53(1), 59-68. https://doi.org/10.1016/j.bushor.2009.09.003

Kotler, P., \& Keller, K. L. (2016). Marketing Management (15 th). Pearson Education.

Maya, S. (2016). Strategi Peningkatan Penjualan Usaha Kecil Menegah Melalui ECommerce Studi Kasus : Mitra UKM Perusahaan X. JABE; Journal of Applied Business and Economics, 2(3), 271-279.

Omotosho, B. J. (2020). Small Scale Craft Workers And The Use Of Social Media Platforms For Business Performance In Southwest Nigeria. Journal of Small Business and Entrepreneurship, 1(1), 1-16. https://doi.org/10.1080/08276331.2020.1764732

Orare, G. A., \& Nkrina, S. (2019). Influence of Internet Marketing Strategies on the Market Share of Online Shops in Nairobi County in. Journal of Marketing Studies, 3(2), 1-19.

Papa, A., Santoro, G., Tirabeni, L., \& Monge, F. (2018). Social media as tool for facilitating knowledge creation and innovation in small and medium enterprises. Baltic Journal of Management, 13(3), 329-344. https://doi.org/10.1108/BJM-04-2017-0125

Priambada, S. (2015). Manfaat Penggunaan Media Sosial Pada Usaha Kecil Menengah (UKM). Seminar Nasional Sistem Informasi Indonesia, November, 41-46.

Purwantini, A. H., \& Anisa, F. (2018). Analisis Pemanfaatan Social Commerce Bagi UMKM: Anteseden dan Konsekuen. Kompartemen: Jurnal Ilmiah Akuntansi, 16(1), 4763. https://doi.org/10.30595/kompartemen.v16i1.2413

Setiawan, T. F., Suharjo, B., \& Syamsun, M. (2018). Strategi Pemasaran Online UMKM Makanan (Studi Kasus di Kecamatan Cibinong). MANAJEMEN IKM, 13(2), 116-126. https://doi.org/10.29244/mikm.13.2.116-126

Siregar, R. T., Silitonga, H. P., \& Putri, J. A. (2020). Strategi Pengembangan Usaha Mikro, Kecil dan Menengah (UMKM) di Kota Pematangsiantar. Jurnal Konsep Bisnis Dan Manajemen, 6(2), 133-142.

Slamet, R., Nainggolan, B., Roessobiyatno, R., Ramdani, H., Hendriyanto, A., \& Ilma, L. L. (2016). Strategi Pengembangan UKM Digital Dalam Menghadapi Era Pasar Bebas. Jurnal Manajemen Indonesia, 16(2), 136-147. https://doi.org/10.25124/jmi.v16i2.319

Sugiyono. (2017). Metode Penelitian Kuantitatif Kualitatif dan R\&D. Alfabeta.

Verma, E., \& Shaiba. (2019). Impact of social media on consumer behaviour. International Journal of Research in Business Studies, 4(1), 117-126. https://doi.org/10.1504/IJIDS.2019.101994

Yasa, N. N. K., Giantari, I. G. A. K., Setini, M., Sarmawa, W., Laksmit, P., Rahmayanti, D., \& Dharmanegara, I. B. A. (2020). Service Strategy Based On Tri Kaya Parisudha, Social Media Promotion, Business Values And Business Performance. Management Science Letters, 10(13), 2961-2972. https://doi.org/10.5267/j.msl.2020.5.029

Zhang, Z., \& Ahmed, W. (2018). A Comparison Of Information Sharing Behaviours Across 379 Health Conditions On Twitter. International Journal of Public Health, 5(Ahmed). 